\title{
Life Cycle Inventories for the Production of Sodium Silicates
}

\author{
Matthias Fawer', Martin Concannon ${ }^{2}$, Wolfram Rieber ${ }^{3}$ \\ 'EMPA (Swiss Federal Laboratories for Materials Testing and Research), Ecology Department, Lerchenfeldstrasse 5, \\ $\mathrm{CH}-9014$ St. Gallen, Switzerland \\ ${ }^{2}$ Crosfield Silicates, Warrington WA5 $1 \mathrm{AB}$, England \\ ${ }^{3}$ Woellner Silikat GmbH, Woellnerstrasse 26, D- 67065 Ludwigshafen, Germany
}

Corresponding author: Dr. Matthias Fawer; e-mail: matthias.fawer@empa.ch

\begin{abstract}
Soluble alkali silicate glasses, liquids and powders are an important class of primary synthetic chemicals and are produced in large quantities both in Europe and world-wide. They are utilised in a broad range of application fields, both industrial and domestic, including detergents, chemical feedstocks, paper manufacture, civil engineering and adhesives. In order to establish viable figures for the consumption of raw materials, water and energy and the emissions to air and water and solid waste generation, the production routes for five typical commercial sodium silicate products were traced back to the extraction of the relevant raw materials from the earth. Life Cycle Inventories for these products were compiled by EMPA St. Gallen / Switzerland on behalf of CEES, a Sector Group of CEFIC, using the data inpur based on the production of 1995 from 12 West European silicate producers covering about $93 \%$ of the total alkaline silicate production in Western Europe.
\end{abstract}

Keywords: Builder; cradle-to-factory-gate; cradle-to-gate; laundry detergents; LCA; LCI; life cycle assessment; Life cycle inventory; sodium silicate; software "EcoPro"

\section{Introduction}

The interest in objective and scientifically based information about the environmental impacts caused by products and everyday life activities has increased with the growing concern of the general public about ecology and the environment. Detergents and cleaning agents have received specific attention, mainly because of the annual consumption of about 5.5 mil. tons of detergent in the EC (situation in 1993); it has become imperative to focus on this category of products in ecological terms.

In 1992, the Association of the Swiss Soap and Detergents Industry (SWI) commissioned Life Cycle Assessments (LCAs) on detergents and cleaning agents by the LCA-Group of EMPA, St. Gallen. The SWI considers that ecobalancing the essential ingredients of these product categories is an important step in the development of the European detergent market. From this first exercise it became obvious that these LCAs are reliable if they can be sponsored by manufacturers of the corresponding ingredients rather than by its users.
The European Detergent Zeolite Producers (ZeoDet) have been first encouraged to carry out a life cycle study on the environmental effects of Zeolite A (FAWER, 1996). One specific sodium silicate has therefore been investigated as a precursor material of Zeolite A. This LCI study has raised the interest of the European Silicate Producers (CEES, Centre Européen d'Etude des Silicates) to carry out Life Cycle Inventories ( $\mathrm{LCl}$ s) of various sodium silicates themselves. The LCIs have accordingly been commissioned by the CEES Sector group of the European Chemical Industry Council (CEFIC) involving 12 member companies.

The idea of the group was to employ an independent institute to generate an authoritative LCI for silicate production in Europe based on individual data supplied by all members. This approach, using an independent 3rd-party, is now a well-established and viable technique which preserves confidentiality and generates meaningful and utilisable LCI data. It has already been successfully applied by the APME (Association of Plastics Manufacturers in Europe) for their ecoprofiles of polymers and by the ECOSOL (European Centre of Studies on Linear Alkylbenzene) for their LCI study on detergent surfactants. This latter work has obviously a direct relevance for the Silicate study. The detailed LCI has been published as EMPA report $N^{\circ} 241$ (FAWER, 1997).

The LCls represent average situations for the sodium silicate production in Western Europe in 1995 and data have been obtained from a total of 13 CEES member production plants which, produced $704,000 \mathrm{t}$ as $\mathrm{SiO}_{2}$ of alkaline silicates in 1995 . This represents $93 \%$ of the total production of alkaline silicate in Western Europe $\left(757,000 \mathrm{t}\right.$ as $\left.\mathrm{SiO}_{2}\right)$.

The average was weighted by the output from each plant. From the supporting group, companies were chosen to provide data for the 5 sodium silicate products. The LCIs are based on data covering the total annual production as outlined in Table 1. For each of the relevant companies an individual LCI has been calculated and sent to cover their respective operations. Each of them will use their own LCI for conducting an internal bench marking of their silicate production. This will help them to identify their priorities in terms of improving their operations and processes. The average LCI has been evaluated for general use and when published will serve clients, consumers and government bodies. 
Table 1: The 5 sodium silicate products: Specification and amount (as $\mathrm{t}$ of $\mathrm{SiO}_{2}$ ) represented by LCI data suppliers

\begin{tabular}{|c|c|c|c|c|}
\hline $\begin{array}{l}1,000 \mathrm{~kg} \\
\text { sodium silicate } \\
3.3 \text { weight ratio } \\
\text { furnace lumps, } \\
100 \% \text { solid }\end{array}$ & $\begin{array}{l}1,000 \mathrm{~kg} \\
\text { sodium silicate } \\
3.3 \text { weight ratio } \\
\text { furnace liquor, } \\
37 \% \text { solid }\end{array}$ & $\begin{array}{l}1,000 \mathrm{~kg} \\
\text { sodium silicate } \\
2.0 \text { weight ratio } \\
\text { hydrothermal } \\
\text { liquor, } 48 \% \text { solid }\end{array}$ & $\begin{array}{l}1,000 \mathrm{~kg} \\
\text { sodium silicate } \\
2.0 \text { weight ratio spray } \\
\text { powder, } \\
80 \% \text { solid }\end{array}$ & $\begin{array}{l}1,000 \mathrm{~kg} \\
\text { sodium meta-silicate } \\
\text { penta- } \\
\text { hydrate (1.0 WR), } \\
58 \% \text { solid }\end{array}$ \\
\hline $260,000 t$ & $300,000 t$ & $91,000 t$ & $15,000 \mathrm{t}$ & $38,000 t$ \\
\hline
\end{tabular}

For convenience, the inventory data are calculated on the basis of the production of $1,000 \mathrm{~kg}$ sodium silicate with standard solid contents of commercially available products. The functionality of the 5 different sodium silicate products is not comparable because their application and performance varies considerably.

The solid portions of the surface of the Earth consist predominantly of silicon and oxygen atoms in the form of silica and silicates. The use of Earth's silica and silicate resources by human beings is the oldest technology on the planet. With the domestication of fire, the first anthropogenic silicates were introduced. The etymological root of the word ceramics goes back through ancient Greek to the Sanskrit verb "to burn" (Rochow, 1987).

The preparation of silicates by chemical reaction began late in the industrial revolution with the production of Portland cement in the 1830s. It was shortly thereafter that soluble alkali silicates were produced on a commercial scale. By 1928, processes were being developed for the use of soluble silicates in aqueous effluent treatment from other industries. The $1940 \mathrm{~s}$ saw the development of aqueous silica sols and the beginnings of the production of crystalline silicates by hydrothermal synthesis. In the following decade, silicones and organic silicates emerged as commercial products. Another decade later a rapid growth occurred in the manufacture of synthetic zeolites, crystalline hydrated aluminosilicates, first as ion exchangers and adsorbents, then as shape selective or molecular sieves and petrochemical catalysts. Today the range of applications falls into three major groups: detergent, chemical and adhesive.

Household laundry detergents incorporate sodium silicate as a builder, corrosion inhibitor and processing aid. Detergents for machine dishwashing and for industrial applications rely on the buffering, saponifying and soil suspension properties.

Sodium silicate is also consumed in large quantities as a silica source for further chemical synthesis. Other chemicals requiring silicates for their manufacture include silica sol and titanium dioxide. Silicates are also used as a chemical auxiliary. They perform an important stabilising role in peroxide bleaching of paper pulp and textiles.

In the third group of applications, silicates function as adhesives. The bonding of paper tubes and drums, for example, utilises sodium silicate as an adhesive in its own right. In other applications, the bonding or setting may be reinforced by heat or chemical reaction.

Soluble silicate glasses, powders and liquids are among the largest volume synthetic chemicals, surpassed in volume only by commodity acids and bases. They are essentially combinations of alkali metal oxide and silica, usually with some water. The general formula for the soluble silicates of sodium, potassium and lithium is:

$x \mathrm{SiO}_{2} \quad \mathrm{M}_{2} \mathrm{O}$ [where $M$ is $\mathrm{Na}, \mathrm{K}$ or $\mathrm{Li}$ and $x$ is the molar ratio (MR) defining the number of moles silica $\left(\mathrm{SiO}_{2}\right)$ per mole of metal oxide $\left(\mathrm{M}_{2} \mathrm{O}\right)$ ].

However, the ratio can also be expressed on a weight basis. For example, a sodium silicate solution containing $36 \% \mathrm{SiO}_{2}$ and $18 \% \mathrm{Na}_{2} \mathrm{O}$ is said to have a weight ratio (WR) of 2.0:1. Since the molecular weights of $\mathrm{Na}_{2} \mathrm{O}(62)$ and $\mathrm{SiO}_{2}(60)$ are similar, there is only a small difference between weight and molar ratio for sodium silicates. For convenience, all ratios in this report are expressed on a weight basis. The versatility of these products stems largely from the modification of their properties made possible by varying the molar ratio and the physical form in which the product is supplied, e.g. liquid, powder, granules, etc.

\section{Goal and Scope}

The idea of the study was to generate quantitative LCI information for the production of 5 sodium silicate products. This information comprises the consumption of energy and raw materials, emissions to air and water and solid waste generation and is presented as "Life Cycle Inventories for the production of Sodium Silicates". The aim was to trace back all production processes to the extraction of raw materials from earth and to calculate average data for the production processes of sodium silicates employed in Europe. Secondary company specific information may be compared with the average $\mathrm{LCI}$ as an internal bench marking process which helps the individual producer to recognise the major potentials of improving their production processes.

More details about the methodology applied and the general aims of a Life Cycle Inventory can be found in the full report (FAWER, 1997). It generally complies with the SETAC publication "A 'Code of Practice' - Guidelines for Life Cycle Assessment" (1993), ISO 14041 (1998) and BUWAL 250 (1996).

The LCI study covered all operations, notably the two basic production processes for sodium silicate (furnace or hydrothermal route) and the further processes (dissolving, blending, filtering, etc.) leading to the 5 commercial products. The study therefore comprises a Chemical Material Inventory or a "Cradle-to-Factory-Gate" study. Subsequent use of sodium silicates in other products (e.g. detergents) and its final disposal were not included. Nevertheless, this basic information on sodium silicates, when combined with other data, allows one to conduct LCIs for full products at a later stage.

Using these LCIs of sodium silicates for comparative studies with alternative materials, special care has to be taken of the equivalent functions. Therefore, detailed information must be collected on the performance of the compared products. 


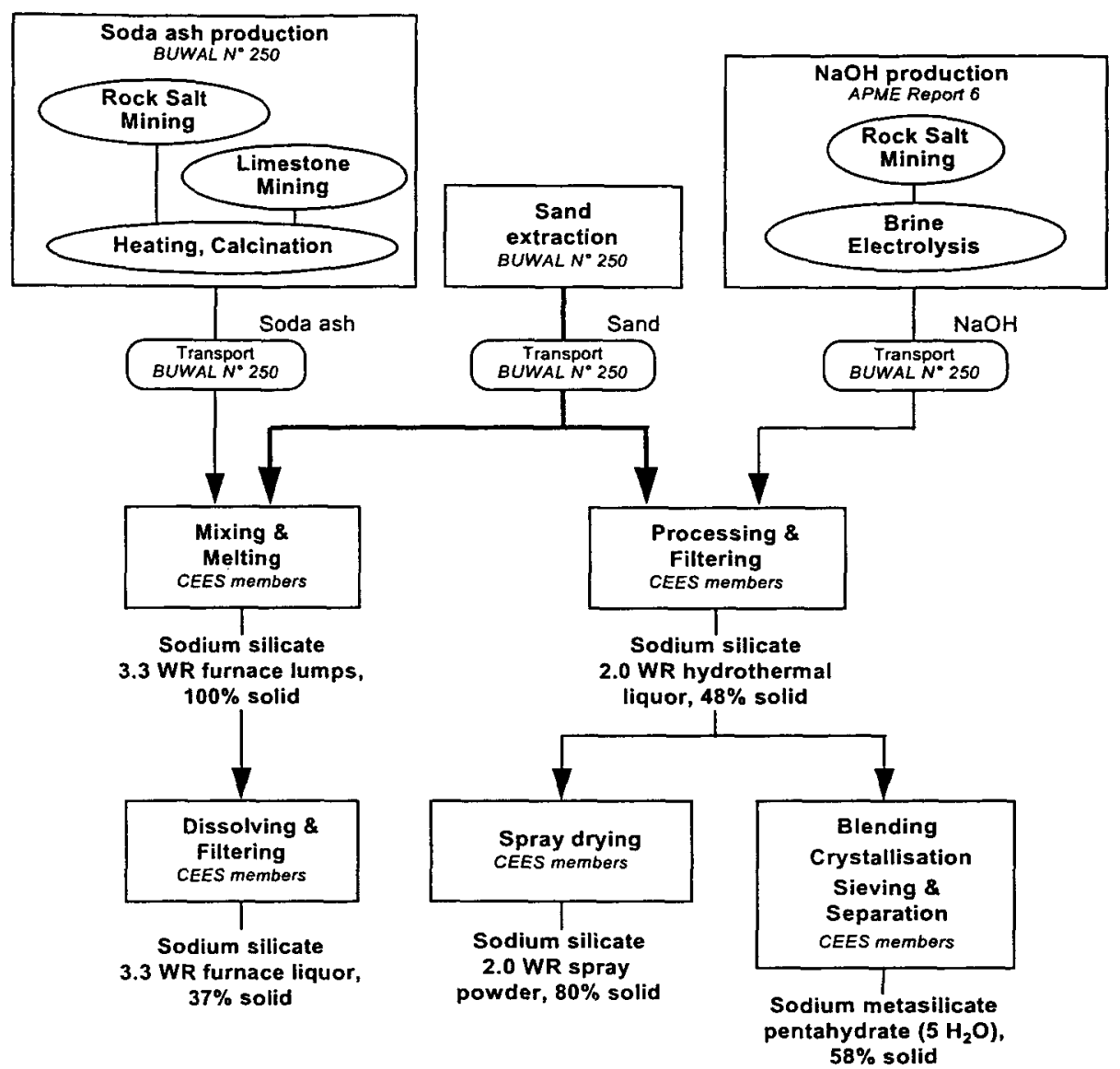

Fig. 1: Schematic flow chart for the production of 5 different sodium silicates. (Italics: Origin of data)

The main production sequence is usually the easiest to identify. This includes the final processes which are under the direct control of the silicate producers and for which operations specific inventory data are used $(\rightarrow$ Fig. 1$)$. All other processes are not under the direct control of the silicate producers and are described by average data (processes with data from $B U W A L N^{\circ} 250$, APME report 6, ETH/ESU study for raw materials, ancillary materials and energy).

The aim, ideally, should be to allow readers and other LCI experts to duplicate the $\mathrm{LCI}$ in exactly the same way as the description of a laboratory experiment should allow the reader to set up the necessary equipment and perform the practical work. Only when the system is described in such detail, can the reader be sure that the system he is visualising is the same as that intended by the author.

\section{Production Routes}

a) Sodium silicate 3.3 WR furnace lumps

Sodium silicate glass WR 3.3 is produced by direct fusion of precisely measured proportions of pure silica sand and soda ash (theoretical values: $767.4 \mathrm{~kg} \mathrm{SiO} / 397.5 \mathrm{~kg} \mathrm{Na}_{2} \mathrm{CO}_{3}$ ) in oil or gas fired furnaces at a temperature of about $1400^{\circ} \mathrm{C}$ according to the reaction:

$\mathrm{Na}_{2} \mathrm{CO}_{3}+x \mathrm{SiO}_{2} \rightarrow x \mathrm{SiO}_{2}: \mathrm{Na}_{2} \mathrm{O}+\mathrm{CO}_{2}$ b) Sodium silicate 3.3 WR furnace liquor ( $37 \%$ solid) From the sodium silicate lumps WR 3.3, the frequently used commercial products are gained by dissolving them in water at elevated temperature and pressure to yield a solution of $37 \%$ solid which is then filtered normally.

c) Sodium silicate 2.0 WR hydrothermal liquor ( $48 \%$ solid) This product is normally produced by hydrothermally dissolving silica sand in sodium hydroxide solution (theoretical values: $320 \mathrm{~kg} \mathrm{SiO}, / 206.5 \mathrm{~kg} \mathrm{NaOH}$ ). the reaction takes place inside autoclaves, specially designed to withstand the extremely aggressive working conditions involved. After filtration, the product is obtained as a sodium silicate solution of $48 \%$ solid and a weight ratio of 2.0 .

\section{d) Sodium silicate 2.0 WR spray powder}

Sodium silicate WR 2.0 Solutions produced according to route c) are dried in drum or spray dryers yielding hydrous powders (about $20 \%$ water) which can readily be redissolved on application (subsequent processing of the powders like compacting or granulating is not contained in the calculations).

\section{e) Sodium metasilicate pentahydrate (1.0 WR / 58\% dry matter)}

This substance is normally produced by blending sodium silicate solutions and additional caustic soda $(\mathrm{NaOH})$ to achieve crystallisable solutions with WR 1.0. The crystallised (stoichiometric) products $\mathrm{Na}_{2} \mathrm{SiO}_{3} \times 5 \mathrm{H}_{2} \mathrm{O}$ are separated, sieved and processed in an appropriate way. 
Table 2: Individual net process energy consumption: weighted average figures and spread for process energy usage

\begin{tabular}{l|l|l}
\hline $\begin{array}{l}\text { Production process } \\
\text { (1,000 kg output) }\end{array}$ & Net Process Energy Consumption [MJ] \\
\hline Furnace process (mixing \& melting) & Average & Spread \\
\hline Furnace lumps dissolving \& filtering & $\mathbf{4 , 1 8 3}$ & $3,700-5,320$ \\
\hline Hydrothermal liquor process (processing \& filtering) & $\mathbf{4 6 7}$ & $345-920$ \\
\hline Na-silicate spray drying process & $\mathbf{5 5 3}$ & $350-680$ \\
\hline Metasilicate process (blending, crystallisation, sieving \& separation) & $\mathbf{7 , 0 0 0}$ & $4,100-13,540$ \\
\hline
\end{tabular}

\section{Remarks to Tabie 2:}

The spread in terms of process energy consumption is due to several parameters which vary over the individual production processes of the five silicate products. Nevertheless, one has to realise that such a spread is not unexpected for the silicate production. It is rather an obvious occurrence when creating average figures over the European production of certain goods involving several plants. In this respect, the spread in energy consumption shown in Table 2 lies within the expectations. However, a few reasons partly explaining the deviation are given below. The following comments are somehow applicable to all described processes.

For instance a higher use of energy may be related to a certain product performance which goes beyond the described functional unit (special filtering step, temperature of sold product, etc.). Furthermore, companies may achieve a higher production yield to avoid the production of waste which also needs additional energy. Another reason for slightly higher energy consumption may be due to spare capacities which necessitates more start-ups and shutdowns of the process.

On the other hand, there may be differences in terms of age and technology of certain installations which result in diverse efficiencies of the systems (heat recovery, energy regime, insulation). A low specific energy consumption can only be achieved with an optimised size of the installation and a perfect energy recovery via steam and electricity generation. Enhanced process design, as for example the dissolving of the lumps straight from the furnace, may also lead to some energy savings. But obviously not all measures are suitable for all production facilities. Therefore, each production site is unique in the way it has developed, has been designed and has been linked to other parts of the plant.

\section{Inventory Results}

\subsection{Average inventory of a unit process}

One purpose of such an LCI study is to help individual companies to compare their specific information with average data of a unit process to elaborate an internal bench-marking process. Therefore, the average input and output figures of the major production (unit) processes for $\mathrm{Na}$-silicate are calculated separately to be compared with company specific data. A special chapter describes the sodium silicate production processes. It is a precise look at an average process that is very useful for engineers of the companies. In contrast to a full LCI, these figures focus on a defined process and the input materials are not traced back to its origin. The average process energy consumptions are shown in Table 2.

\subsection{Average Life Cycle Inventory (L.Cl) $(\rightarrow$ Table 3, Appendix)}

The Life Cycle Inventory results are presented in a complete input-output table. They display results for raw materials and water consumption, electricity and thermal energy use, emissions to air and water and solid waste generation (including the consumptions and emissions caused by intermediates and energy production and transport).

The whole LCIs have been calculated using EMPA software "EcoPro 1.4". This newly developed software contains standard data modules which may be combined with additional figures from industry.

\section{Conclusions}

The LCIs of sodium silicates were carried out using the latest information about silicate production processes and the precombustion of required intermediates and energies. The data presented here for the manufacture of sodium silicates are therefore a good representation of average European practice during the year 1995 . The methodology applied in this study is in compliance with the described standard procedures of SETAC and ISO.

These LCIs for sodium silicates are an important step within a Life Cycle Assessment (LCA), providing data on defined processes. They take into account material and energy inputs and outputs such as emissions to land, air and water. These LCIs are not an LCA study in their own right, but provide the raw dara on which such studies, including comparisons and assessments, can be based. Each of the companies involved knows their own LCI and is therefore able to compare their figures with the average LCIs for sodium silicates and to determine any ecological weak points or identify any production process improvement opportunities (Hot spot analysis). This identification of critical aspects of the silicate production processes was already part of an iterative data collection procedure. With each iteration step ( 3 in total) an increasing level of detail and reliability was attained. The level of detail was increased on points where the previous iteration pointed out key issues for further analysis. Issues like raw material use, energy consumption, steam partition within one site and functional units (e.g. solid content and weight ratio of final products) were especially addressed during this iterative procedure. Furthermore, such a data collection is considered to be a dynamic activity and, ideally, should be repeated periodically approximately every 5 years.

The LCI data generated in this study may subsequently be used to conduct full LCAs for a variety of systems, for instance detergent products. In particular, they can provide a basis for comparing the environmental characteristics of different systems. Above all, this necessitates the correct specification of the functional unit of such systems in a way that the performances delivered are equivalent. Defining such 
functionality is a specialised undertaking in which all pertinent attributes of the systems and of the products themselves must be considered.

\section{Acknowledgements}

This compilation of LCls has been commissioned and sponsored by CEES (Centre Européen d'Etude des Silicates) involving the following member companies most of whom have also supplied their specific process data:

AKZO-PQ Silica Vof

Ausimont

Crosfield Ltd.

FMC foret S.A

Henkel KGaA

IQE S.A.

Rhodia

(former Rhône-Poulenc S.A.)

SILMACO S.A

Clariant

(former Société Française Hoechst)

Van Baerle GmbH

Van Baerle \& Cie AG

Woellner Silikat GmbH

\begin{tabular}{|c|c|}
\hline $\begin{array}{l}\text { Amersfoort } \\
\text { Bollate } \\
\text { Warrington } \\
\text { Barcelona } \\
\text { Düsseldort } \\
\text { Zaragoza } \\
\text { Courbevoie }\end{array}$ & $\begin{array}{l}\text { Netherlands } \\
\text { Italy } \\
\text { England } \\
\text { Spain } \\
\text { Germany } \\
\text { Spain } \\
\text { France }\end{array}$ \\
\hline $\begin{array}{l}\text { Lanaken } \\
\text { Cuise-Lamotte }\end{array}$ & $\begin{array}{l}\text { Belgium } \\
\text { France }\end{array}$ \\
\hline $\begin{array}{l}\text { Gernsheim } \\
\text { Münchenstein } \\
\text { Ludwigshafen }\end{array}$ & $\begin{array}{l}\text { Germany } \\
\text { Switzerland } \\
\text { Germany }\end{array}$ \\
\hline
\end{tabular}

\section{References}

Boustrad, 1. (1992): Eco-profiles of the European polymer industry, Report 1: Eco-balance methodology for commodity thermoplastics. Association of Plastics Manufacturers in Europe (APME), Brussels

BoustE.AD, I. (1994): Eco-profiles of the European polymer industry, Report 6: Polyvinyl chloride. Association of Plastics Manufacturers in Europe (APME), Brussels
BUWAL (1996): Environmental Inventories of packaging materials. Environmental Series $\mathrm{N}^{\circ} 250$. Swiss Federal Office of Environment, Forests and Landscape (BUWAL), Bern

Falcone Jr., J.S.; BlumberG, J.G. (1992): Anthropogenic silicates, in: The Handbook of Environmental Chemistry, Vol. 3, Part F, Springer, Berlin Heidelberg New York

FAWER, M: (1996): Life Cycle Inventory for the production of Zeolite A for detergents. EMPA report Nr. 234, Dübendorf. Commissioned by ZeoDet, a sector group of CEFIC

FAWER, M. (1997): Life Cycle Inventory for the production of Sodium Silicates. EMIPA report Nr. 241, Dübendorf. Commissioned by CEES, a sector group of CEFIC

FrISCHKNECHT, R. et al. (1993): Environmental Life Cycle Inventories for energy systems. Swiss Federal Institute of Technology ETH Zurich, Institute für Energietechnik (ESU)

ISO 14040 (1997): Environmental management - Life cycle assessment - Principles and guidelines

ISO 14041 (1998): Environmental management - Life cycle assessment - Goal and scope definition and inventory analysis

RoCHOw, E.G. (1987): Silicon and silicones, Springer, Berlin Heidelberg New York

SETAC (1993): A 'Code of Practice'. Guidelines for Life-Cycle Assessment. Society of Environmental Toxicology and Chemistry (SETAC). Outcome of Workshop in Sesimbra, Portugal

SPOLD (1996): Introduction into a common format for life cycle inventory data, prepared by Axel Singhofen, Brussels; Int. J. LCA 1 (3) 171-178 (1996)

\section{Appendix}

Received: May 19th, 1999 Accepted: June 23, 1999

Table 3: Average LCls for the production of the five sodium silicate products

\begin{tabular}{|c|c|c|c|c|c|c|}
\hline \multicolumn{7}{|c|}{ LCI of various Sodium Silicates } \\
\hline Weighted average & & $\begin{array}{c}\text { Na-silicate } 3,3 \\
\text { (WR) furnace lumps. } \\
100 \%\end{array}$ & $\begin{array}{l}\text { Na-silicate } 3.3 \\
\text { (WR) furnace liquor, } \\
37 \% \text { solid }\end{array}$ & $\begin{array}{l}\text { Na-silicate } 2.0 \\
\text { (WR) hydrothermal } \\
\text { liquor, } 48 \% \text { solid }\end{array}$ & $\begin{array}{c}\text { Na-silicate } 2.0 \\
\text { (WR) spray oowder. } \\
80 \% \text { solid }\end{array}$ & $\begin{array}{c}\text { Na-metasilicate } \\
\text { Pentahydrate } \\
(1.0 \text { WR }), 58 \% \text { solid }\end{array}$ \\
\hline Funktional unit & & $1,000 \mathrm{~kg}$ & $1,000 \mathrm{~kg}$ & $1,000 \mathrm{~kg}$ & $1,000 \mathrm{~kg}$ & $1.000 \mathrm{~kg}$ \\
\hline \multicolumn{7}{|l|}{ Raw materials } \\
\hline $\begin{array}{l}\text { Rock salt } \\
\text { Sand } \\
\text { Lime stone }\end{array}$ & $\begin{array}{l}\mathrm{kg} \\
\mathrm{kg} \\
\mathrm{kg}\end{array}$ & $\begin{array}{l}638 \\
772 \\
510 \\
\end{array}$ & $\begin{array}{l}237 \\
287 \\
190 \\
\end{array}$ & $\begin{array}{l}123 \\
325 \\
2.2 \\
\end{array}$ & $\begin{array}{l}214 \\
562 \\
3.8 \\
\end{array}$ & $\begin{array}{l}224 \\
293 \\
4.0 \\
\end{array}$ \\
\hline \multicolumn{7}{|c|}{ Intermediates for Na-silicate prod. } \\
\hline $\begin{array}{l}\text { Washed sand (100\% dry) } \\
\text { Soda } \\
\mathrm{NaOH}(100 \%)\end{array}$ & $\begin{array}{l}\mathrm{kg} \\
\mathrm{kg} \\
\mathrm{kg}\end{array}$ & $\begin{array}{l}772 \\
400\end{array}$ & $\begin{array}{l}287 \\
149\end{array}$ & $\begin{array}{l}325 \\
209 \\
\end{array}$ & $\begin{array}{l}562 \\
362 \\
\end{array}$ & $\begin{array}{l}293 \\
380\end{array}$ \\
\hline \multicolumn{7}{|c|}{ Auxil. Materials for Na-silicate prod. } \\
\hline $\begin{array}{l}\text { Water for steam prod. } \\
\text { Compressed air [ } 8 \text { bar] } \\
\text { "Additives }\end{array}$ & $\begin{array}{r}\mathrm{m}^{3} \\
\mathrm{Nm}^{3} \\
\mathrm{~kg}\end{array}$ & $\begin{array}{l}7.3 \\
9.6 \\
0.1 \\
\end{array}$ & $\begin{array}{l}115 \\
8.4 \\
0.7 \\
\end{array}$ & $\begin{array}{c}142.8 \\
4.0 \\
0.7 \\
\end{array}$ & $\begin{array}{c}815.3 \\
115.9 \\
1.6 \\
\end{array}$ & $\begin{array}{c}343.1 \\
28.6 \\
0.6\end{array}$ \\
\hline \multicolumn{7}{|c|}{ Energy Flow (delivered energy) } \\
\hline $\begin{array}{l}\text { Electricity } \\
\text { Coal } \\
\text { Oil heavy } \\
\text { Oil average/light } \\
\text { Diesel oil } \\
\text { Gas } \\
\text { Others } \\
\end{array}$ & $\begin{array}{l}\mathrm{MJ} \\
\mathrm{MJ} \\
\mathrm{MJ} \\
\mathrm{MJ} \\
\mathrm{MJ} \\
\mathrm{MJ}\end{array}$ & $\begin{array}{c}477 \\
4,501 \\
2,981 \\
297 \\
157 \\
3,243 \\
7 \\
\end{array}$ & $\begin{array}{c}212 \\
1,710 \\
1,310 \\
110 \\
57 \\
1,404 \\
61 \\
\end{array}$ & $\begin{array}{c}3,118 \\
296 \\
9 \\
456 \\
144 \\
1,270 \\
78 \\
\end{array}$ & $\begin{array}{c}7.075 \\
517 \\
12 \\
789 \\
211 \\
8,290 \\
1.097 \\
\end{array}$ & $\begin{array}{c}6,41 \\
487 \\
6 \\
715 \\
262 \\
2,66 \\
36 \\
\end{array}$ \\
\hline Sub-total & $\mathrm{MJ}$ & 11,661 & 4,865 & 5,371 & 17,992 & 10,57 \\
\hline Recovered energy & $\mathrm{MJ}$ & 708 & 242 & & & \\
\hline Total & $\mathrm{MJ}$ & 10,953 & 4,623 & 5.371 & 17,992 & 10,57 \\
\hline \multicolumn{7}{|l|}{ Recyclable materials } \\
\hline $\begin{array}{l}\text { Water } \\
\text { Filter residues }\end{array}$ & $\begin{array}{l}\mathrm{kg} \\
\mathrm{kg}\end{array}$ & 67.5 & $\begin{array}{c}75.3 \\
1.0\end{array}$ & $\begin{array}{l}68.6 \\
0.7\end{array}$ & 502 & $\begin{array}{c}510,7 \\
0.8\end{array}$ \\
\hline
\end{tabular}


Table 3 continued

\begin{tabular}{|c|c|c|c|c|c|c|}
\hline \multicolumn{7}{|c|}{ LCl of various Sodium Silicates } \\
\hline $\begin{array}{l}\text { Weighted average } \\
\text { Funktional unit }\end{array}$ & & $\begin{array}{c}\text { Na-silicate } 3,3 \\
\text { (WR) furnace lumps, } \\
100 \% \\
1,000 \mathrm{~kg}\end{array}$ & $\begin{array}{c}\text { Na-silicate } 3.3 \\
\text { (WR) furnace liquor, } \\
37 \% \text { solid } \\
1,000 \mathrm{~kg}\end{array}$ & $\begin{array}{c}\text { Na-silicate } 2.0 \\
\text { (WR) hydrothermal } \\
\text { liquor, } 48 \% \text { solid } \\
1.000 \mathrm{~kg}\end{array}$ & $\begin{array}{c}\text { Na-silicate } 2.0 \\
\text { (WR) spray powder, } \\
80 \% \text { solid } \\
1,000 \mathrm{~kg}\end{array}$ & $\begin{array}{c}\text { Na-metasilicate } \\
\text { Pentahydrate } \\
(1.0 \mathrm{WR}) .58 \% \text { solid } \\
1,000 \mathrm{~kg}\end{array}$ \\
\hline \multicolumn{7}{|l|}{ Solid waste } \\
\hline $\begin{array}{l}\text { Mineral waste } \\
\text { Filter residues } \\
\text { Inert chemicals } \\
\text { Slags \& ash } \\
\text { Regulated chemicals }\end{array}$ & $\begin{array}{l}\mathrm{kg} \\
\mathrm{kg} \\
\mathrm{kg} \\
\mathrm{kg} \\
\mathrm{kg}\end{array}$ & $\begin{array}{l}127 \\
0.6\end{array}$ & $\begin{array}{c}47.2 \\
0.9 \\
0.3\end{array}$ & $\begin{array}{c}20.2 \\
1.2 \\
1.7 \\
2.3 \\
0.004\end{array}$ & $\begin{array}{c}28.9 \\
4.1 \\
3.0 \\
4.0 \\
0.01\end{array}$ & $\begin{array}{c}27.6 \\
2.8 \\
3.7 \\
4.2 \\
0.01\end{array}$ \\
\hline \multicolumn{7}{|l|}{ Air emissions } \\
\hline $\begin{array}{l}\text { Ammonia (NH3) } \\
\text { Carbon dioxide fossil }\left(\mathrm{CO}_{2}\right) \\
\text { Carbon monoxide } \\
\text { Dust, particles } \\
\text { Methane (CH4) } \\
\text { Nitrogen oxides (NO, }) \\
\text { Non methan hc (NMVOC) } \\
\left.\text { Sulphur oxides ( } \mathrm{SO}_{x}\right) \\
\end{array}$ & $\begin{array}{l}g \\
g \\
g \\
g \\
g \\
g \\
g \\
g\end{array}$ & $\begin{array}{c}237 \\
1,066,022 \\
3,748 \\
3,886 \\
666 \\
3,606 \\
1,035 \\
4,699 \\
\end{array}$ & $\begin{array}{c}88.3 \\
424,668 \\
1,406 \\
1,454 \\
307 \\
1,424 \\
420 \\
1,914 \\
\end{array}$ & $\begin{array}{c}0.03 \\
288,698 \\
218 \\
667 \\
128 \\
1,748 \\
1,451 \\
2,186 \\
\end{array}$ & $\begin{array}{c}0.3 \\
892,353 \\
509 \\
1,509 \\
1,338 \\
3,490 \\
2,588 \\
4,181 \\
\end{array}$ & $\begin{array}{c}0.2 \\
570.190 \\
404 \\
1,257 \\
371 \\
3,26 \\
2.63 \\
4,08 \\
\end{array}$ \\
\hline \multicolumn{7}{|l|}{ Water emissions } \\
\hline $\begin{array}{l}\text { Ammonium (NH4+) } \\
\text { BOD as } \mathrm{g} \mathrm{O}_{2} \\
\text { Chlorides }(\mathrm{Cl}-) \\
\mathrm{COD} \text { as } \mathrm{g} \mathrm{O}_{2} \\
\text { Inorg. Salts and acids } \\
\text { Metals } \\
\text { Suspended solids } \\
\end{array}$ & $\begin{array}{l}\mathrm{g} \\
\mathrm{g} \\
\mathrm{g} \\
\mathrm{g} \\
\mathrm{g} \\
\mathrm{g} \\
\mathrm{g}\end{array}$ & $\begin{array}{c}121.6 \\
0.35 \\
374,589 \\
3.9 \\
229,533 \\
26.5 \\
28,752 \\
\end{array}$ & $\begin{array}{c}45.4 \\
0.14 \\
139,365 \\
1.6 \\
85.413 \\
11.5 \\
10,704 \\
\end{array}$ & $\begin{array}{c}0.6 \\
0.65 \\
6.316 \\
9.8 \\
1,034 \\
17.3 \\
892 \\
\end{array}$ & $\begin{array}{c}1.4 \\
1.15 \\
11.197 \\
6.3 \\
2,066 \\
35.2 \\
4,196 \\
\end{array}$ & $\begin{array}{c}1.0 \\
1.18 \\
11.546 \\
14.1 \\
4.537 \\
32.8 \\
605 \\
\end{array}$ \\
\hline Water consumption & & 7.3 & 3.5 & 1.9 & 5.1 & 3.5 \\
\hline
\end{tabular}

\title{
News \& Views: EMPA Report No. 244
}

\section{Life Cycle Inventories for the Production of Detergent Ingredients}

\author{
Silvio Dall'Acqua, Dr. Matthias Fawer, Renato Fritschi, Caroline Allenspach
}

1999, 109 pages, bound, incl. 3.5" diskettes with excel data files, CHF 100.-/ Euro 62.-

Engl.: ISBN 3-905594-09-9; Germ.: ISBN 3-905594-08-0; ISSN 0258-9745

This study (commissioned by the German Federal Environmental Agency, UBA Berlin and the Ökoinstitut Freiburg, Germany) presents basic data on the production of the most important ingredients for detergents. These data have been harmonised and updated and are published as life cycle inventories.

Two different groups are targeted. The first is the users of these LCIs from the detergent industry. The second target group consists of the LCA experts in general. The problem of LCIs that are incompatible due to the use of varied methodologies and basic data is a common one. This study can be helpful in demonstrating solutions for these problems.

Applying the data published here eliminates concerns over whether the data are compatible with each other, and they can therefore be combined quickly and simply. Users of these data can be sure that:

- A uniform methodology, which is compliant with ISO $14000 \mathrm{ff}$, has been applied in the life cycle inventories

- Joint basic data on energy production, transport and basic chemicals have been used
- The LCI parameters are compatible with each other

- The structure of the individual LCIs is constant

It is thus possible for users to obtain reliable and meaningful results. Through the qualitative descriptions in the individual inventories, they can also quickly recognise whether the data are appropriate to their needs.

\section{Summary of the Table of Contents}

- Basic introduction in the field of detergent ingredients

- Detailled description of the LCI methodology applied

- Description of the individual ingredients and performed amendments and methodological variations

- Basic data and life cycle inventories

- Critical review report by Dr. Rolf Bretz, Ciba SC

- Statement on the critical review report

- Comparison of different terms used for parameters

- Glossary of terms

- Standard questionnaire for collecting data

Send your order to: EMPA St. Gallen, Section Ecology, Lerchenfeldstr. 5, CH-9014 St. Gallen, Switzerland; Tel. +41 712747441 ; Fax +41 7127478 62; e-mail: ecology@empa.ch; http://www.empa.ch 